Article

\title{
Fungal Strains as Catalysts for the Biotransformation of Halolactones by Hydrolytic Dehalogenation with the Dimethylcyclohexane System
}

\author{
Malgorzata Grabarczyk \\ Department of Chemistry, University of Environmental and Life Sciences, Norwida 25, \\ 50-375 Wrocław, Poland; E-Mail: magrab@onet.pl; Tel.: +48-71-3205-252; Fax: +48-71-3207-744
}

Received: 26 June 2012; in revised form: 30 July 2012 / Accepted: 1 August 2012 /

Published: 14 August 2012

\begin{abstract}
Bicyclic chloro-, bromo- and iodo- $\gamma$-lactones with dimethylcyclohexane rings were used as substrates for bioconversion by several fungal strains (Fusarium, Botrytis and Beauveria). Most of the selected microorganisms transformed these lactones by hydrolytic dehalogenation into the new compound cis-2-hydroxy-4,6-dimethyl-9-oxabicyclo[4.3.0]nonan-8-one, mainly the (-)-isomer. When iodo- $\gamma$-lactone was used as the substrate, two products were observed: a hydroxy- $\gamma$-lactone and an unsaturated lactone. The structures of all substrates and products were established on the basis of their spectral data. The mechanism of dehalogenation of three halolactones was also studied.
\end{abstract}

Keywords: lactones; biotransformation; hydrolytic dehalogenation; Fusarium species

\section{Introduction}

Halogenated organic compounds are often found in Nature. They are typically isolated from many marine organisms such as red algae, bacteria, sponges and corals. Among them there are found sesquiterpenoids [1-3], diterpenoids [4-6], lactones [7,8] and macrolides [9,10]. Halocompounds can be used as therapeutic agents and they have different biological properties such as anticancer [11,12], cytotoxic [13-17], antimicrobial [18] and antimalarial [19] activities. Halogenated organic compounds are also used as solvents, as intermediates for chemical syntheses and also as pesticides or artificial fertilisers. Such compounds are theoretically good because they protect our food from pests and they have a positive effect on crop growth, but they can accumulate in soil or in water. As a consequence, in large amounts, they can be poisonous to other animals or fish [20,21]. 
There are many different methods used for the biodegradation of halocompounds containing aromatic rings using algae [22,23], bacteria [24-26], fungi [27-30]. There are fewer reports about dehalogenation of non-aromatic compounds. Bacteria have been used to biodegrade different aliphatic compounds [31-33]. Various fungal strains were used for biodegradation of terpenoid halo-lactones [34-36]. These fungal strains are mainly able to introduce a hydroxy group in the place of the halogen atom or to eliminate the halogen through the formation of a double bond.

Filamentous fungi of the genus Fusarium, Beauveria and Botrytis are known for their hydrolytic properties in relation to miscellaneous compounds. Filamentous fungi of the genus Fusarium were often used for biohydroxylation of different substrates such as sesquiterpenoids [37], diterpenoids [37-41], steroids [42], sesquiterpene lactones [43-45], nitriles [46] and flavonoids [47]. An interesting example of biohydroxylation is the use of Fusarium oxysporum for the production of $\alpha$-terpineol (a commonly used fragrance compound) [48,49]. The fungal strain Beauveria bassiana was used for biohydroxylation of hydrocarbons [50], sesquiterpenes [50,51], diterpenes [52], lactone lovastatin [53] amides [50]. The filamentous fungus Botrytis cinerea was also used to introduce hydroxy groups on different substrates like monoterpenes [37], sesquiterpenoids [54,55], steroids [54] or halogenated aromatic compound [56].

Bearing in mind that the fact that there are many reports about biological hydroxylation, but very few of them concern the hydrolytic dehalogenation of halolactones, therefore, in this study, further examples of the biohydroxylation of chloro-, bromo- and iodolactones with a dimethylcyclohexane ring are shown. Halolactones have been chosen as model compounds because some of them exhibit antifeeding activity against different insect pests and they can be used in insect pest control [57-62]. Additionally, halolactones are relatively simple to synthesise in good yield. Using these lactones as substrates led me to select microorganisms which are able to eliminate a halogen atom from a molecule. An additional advantage of this method is that fungal strains often introduce a hydroxy group into the molecule, providing hydroxylactones which are different than those obtained using the classical synthetic methods.

\section{Results and Discussion}

The substrates used for biotransformation were the racemic halolactones 3-5. They were all synthesised from a known $\gamma, \delta$-unsaturated ester $\mathbf{1}$ (Scheme 1). Iodolactone $\mathbf{5}$ was obtained by basic hydrolysis of ester $\mathbf{1}$ and iodolactonisation of acid $\mathbf{2}$ according to the procedure described earlier [63]. Lactones $\mathbf{3}$ and $\mathbf{4}$ were also obtained in two steps: basic hydrolysis of ester $\mathbf{1}$ and bromo- or chlorolactonization using $N$-bromosuccinimide (NBS) or $N$-chlorosuccinimide (NCS), respectively.

The structures of chloro- $\gamma$-lactone 3 and bromo- $\gamma$-lactone 4 were determined on the basis of their spectral data $\left({ }^{1} \mathrm{H}-\mathrm{NMR},{ }^{13} \mathrm{C}-\mathrm{NMR}, \mathrm{COSY}, \mathrm{HMQC}\right.$ and IR) and elemental analysis. The absorption bands at $1788 \mathrm{~cm}^{-1}$ for 3 and $1789 \mathrm{~cm}^{-1}$ for $\mathbf{4}$ in their IR spectra confirmed the presence of a $\gamma$-lactone ring in the structure of these compounds. The similarity between the spectral data $\left({ }^{1} \mathrm{H}-\mathrm{NMR}\right)$ of chlorolactone $\mathbf{3}$, bromolactone 4 and the previously obtained iodolactone 5 [63] suggested that their structures were identical. In all three cases, the cyclohexane ring was found in the chair conformation. The signal of proton H-1 in the NMR spectra looked like a broad singlet. The multiplet of proton 
$\mathrm{H}-2$ had very small coupling constants. This indicates that both $\mathrm{H}-1$ and $\mathrm{H}-2$ protons were in trans-diequatorial positions.

Scheme 1. Synthesis of halolactones 3-5.

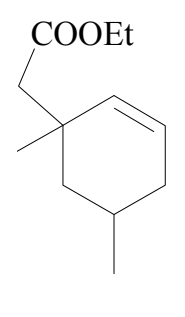

1

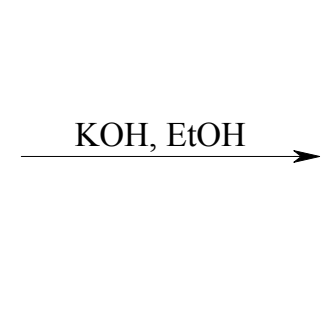

3

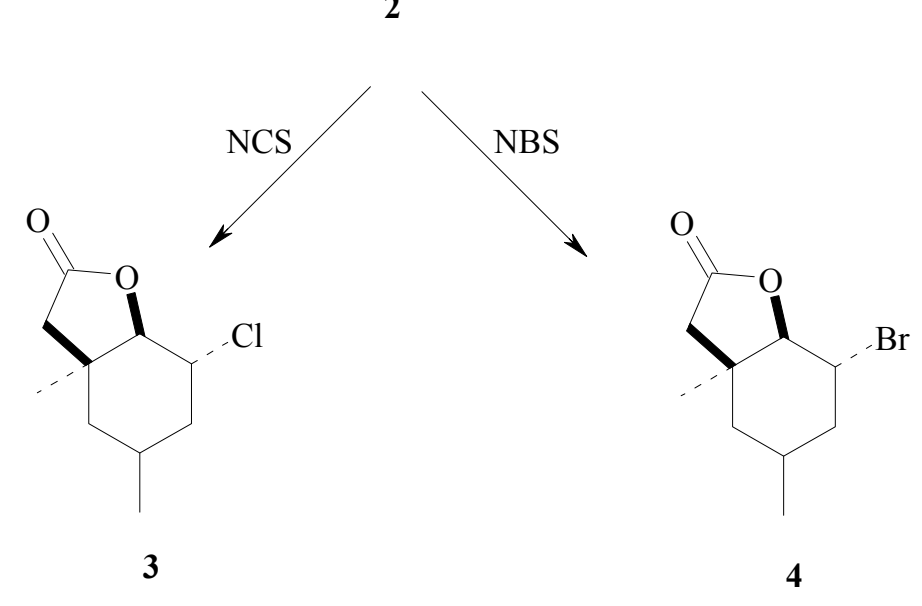

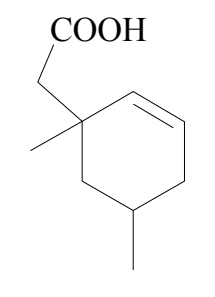

2
$\mathrm{O}$
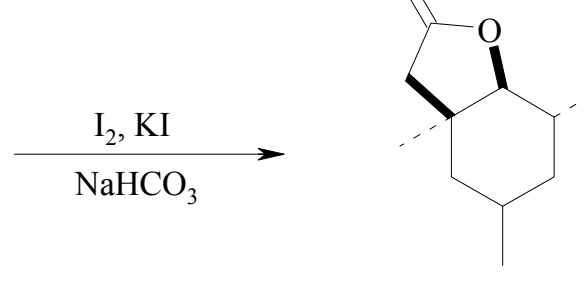

5

Biotransformations were carried out in two steps: first, the screening transformation and then the preparative one. During the screening procedure, eight fungal strains of local origin: Fusarium culmorum, Fusarium avenaceum, Fusarium oxysporum, Fusarium tricinctum, Fusarium semitectum, Fusarium solani, Botrytis cinerea and Beauveria bassiana were tested for their ability to convert halolactones into other products. The progress of all the biotransformations was monitored by means of standard techniques (TLC and GC). All known products (1, 2, 5 and 7) obtained during syntheses or biotransformation were analyzed on a HP-5 column on the basis of their retention times due to with their known patterns obtained earlier in our team [63]. The retention times of new and expected products (3 and 4) were compared with the analogous ones obtained previously [35]. During the biotransformation of chloro- $\mathbf{3}$ and bromolactone $\mathbf{4}$ only two peaks coming from the substrate and the product were observed in the chromatogram, whose relationship changed over time. The structures of all obtained products were then confirmed by spectroscopic methods $\left({ }^{1} \mathrm{H}-\mathrm{NMR},{ }^{13} \mathrm{C}-\mathrm{NMR}\right.$, COSY, HMQC and IR) and also elemental analysis.

The composition of the product mixture shows that, when chloro- $\mathbf{3}$ and bromolactone $\mathbf{4}$ were used as substrates, hydroxylactone $\mathbf{6}$ was obtained as the only product. During the transformation of iodolactone 5, the formation of the same hydroxylactone $\mathbf{6}$ was observed and in four cases (when $F$. culmorum, $F$. solani, $F$. avenaceum and $F$. semitectum were used as biocatalysts) the unsaturated lactone 7 [63] (Scheme 2, Table 1) was obtained too. 
Scheme 2. Biotransformations of halolactones 3-5.

$\mathrm{O}$

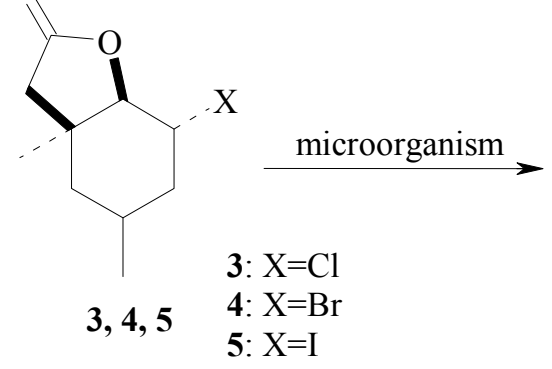

$\mathrm{O}$

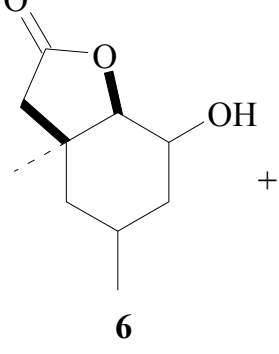

$\mathrm{O}$

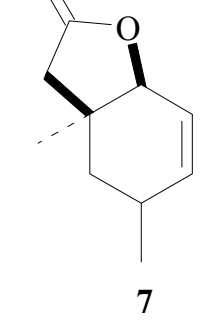

Table 1. The composition (in \% according to GC) of the product mixtures of screening biotransformations of lactones $3, \mathbf{4}, \mathbf{5}$.

\begin{tabular}{|c|c|c|c|c|c|}
\hline \multirow{2}{*}{ Strain } & \multirow{2}{*}{$\begin{array}{c}\text { Time of } \\
\text { incubation } \\
\text { (days) }\end{array}$} & \multicolumn{4}{|c|}{ Products of transformations (\%) } \\
\hline & & $6($ from 3$)$ & 6 (from 4) & 6 (from 5) & 7 (from 5) \\
\hline Fusarium & 5 & - & 19.5 & 10.3 & 28.5 \\
\hline culmorum & 9 & 5.0 & 54.1 & 22.7 & 41.2 \\
\hline AM10 & 14 & 7.4 & 75.1 & 35.5 & 51.8 \\
\hline Fusarium & 5 & - & 7.8 & 4.8 & 1.4 \\
\hline avenaceum & 9 & 27.4 & 48.2 & 10.4 & 2.9 \\
\hline AM11 & 14 & 57.7 & 56.3 & 15.9 & 6.3 \\
\hline Fusarium & 5 & 9.1 & 1.5 & 2.5 & - \\
\hline oxysporum & 9 & 40.5 & 27.6 & 36.3 & - \\
\hline AM13 & 14 & 60.4 & 65.5 & 52.0 & - \\
\hline Fusarium & 5 & - & 10.8 & 3.1 & - \\
\hline tricinctum & 9 & 20.9 & 24.7 & 16.4 & - \\
\hline AM16 & 14 & 53.3 & 52.4 & 24.8 & - \\
\hline Fusarium & 5 & 5.7 & 6.6 & 10.5 & 11.0 \\
\hline semitectum & 9 & 16.7 & 30.3 & 22.7 & 20.0 \\
\hline AM20 & 14 & 51.4 & 55.9 & 42.0 & 9.3 \\
\hline Fusarium solani & 5 & 1.8 & 27.7 & 2.7 & - \\
\hline \multirow[t]{2}{*}{ AM203 } & 9 & 33.0 & 48.7 & 35.8 & 6.5 \\
\hline & 14 & 76.6 & 61.1 & 54.7 & 7.7 \\
\hline Botrytis cinerea & 5 & 3.3 & 3.6 & 7.3 & - \\
\hline \multirow[t]{2}{*}{ AM235 } & 9 & 84.1 & 56.6 & 24.3 & - \\
\hline & 14 & 85.3 & 95.0 & 27.7 & - \\
\hline Beauveria & 5 & 6.1 & 3.3 & 3.5 & - \\
\hline bassiana & 9 & 22.3 & 18.7 & 10.2 & - \\
\hline AM278 & 14 & 29.7 & 26.5 & 19.7 & - \\
\hline
\end{tabular}

These results indicated that all three substrates, chloro- $\mathbf{3}$, bromo- $\mathbf{4}$ and iodolactone $\mathbf{5}$, were always transformed into the same product-hydroxylactone 6. An additional product (unsaturated lactone 7) was observed only for iodolactone $\mathbf{5}$, in three cases in small quantities and in one (when Fusarium culmorum was used) in good yield. Two microorganisms, Fusarium oxysporum and Fusarium solani, transformed all three substrates with good yields (respectively 52\%-60\% and 55\%-77\%). Using 
Botrytis cinerea led to products from chloro- and bromolactone with high yield ( $85 \%$ and $95 \%)$. The other fungal strains converted one or two substrates with satisfactory yield (between $52 \%$ and $75 \%$ ). During these screening transformations, only the percentage of conversion was checked.

For all three lactones (compounds 3, 4 and 5), the abiotic control was carried out by adding each one of them to a sterile medium containing $3 \mathrm{~g}$ glucose and $1 \mathrm{~g}$ peptobac in water $(100 \mathrm{~mL})$ and shaking for two weeks. The samples were taken as in the case of the screening procedure. As a result of the experiments, it was found that only the substrate was always in the reaction mixture. This means that the hydrolytic dehalogenation of these halolactones does not occur without the presence of the microorganisms. Another experiment was then carried out. The fungal strains were incubated for 14 days without the addition of substrate. This allowed me to find the secondary metabolites produced by the tested strains.

The next step of preparative biotransformations was to find fungal strains which were capable of converting the substrates in yields over 50\%. Different Fusarium species and Botrytis cinerea were chosen for this purpose. The results of these transformations are shown in Tables 2-4.

The structures of the two products 6 and 7 were established on basis of their spectral data. The IR spectra showed that the $\gamma$-lactone ring had been retained during the biotransformation in both products (absorption bands at $1788 \mathrm{~cm}^{-1}$ and $1779 \mathrm{~cm}^{-1}$, respectively). A strong, broad band found at $3292 \mathrm{~cm}^{-1}$ for 6 suggested the presence of a hydroxy group in the molecule.

Table 2. Results of preparative biotransformations of lactone 3 after 14 days.

\begin{tabular}{ccccccc}
\hline Strain & $\mathbf{3}(\mathbf{\%})$ & $\mathbf{6}(\mathbf{\%})$ & $\begin{array}{c}\text { Isolated } \\
\text { yield (\%) }\end{array}$ & $\begin{array}{c}\text { Isolated } \\
\text { yield (g) }\end{array}$ & $\boldsymbol{e e ~ ( \% )}$ & $\alpha_{D}^{20}$ \\
\hline F. avenaceum AM11 & 43.2 & 56.8 & 31.8 & 0.029 & 6.7 & $+6.92\left(c=1.06, \mathrm{CHCl}_{3}\right)$ \\
F. oxysporum AM13 & 39.0 & 61.0 & 26.3 & 0.024 & 15.8 & $-7.45\left(c=0.93, \mathrm{CHCl}_{3}\right)$ \\
F. tricinctum AM16 & 25.8 & 74.2 & 36.2 & 0.033 & 25.8 & $-14.12\left(c=0.60, \mathrm{CHCl}_{3}\right)$ \\
F. solani AM203 & 12.2 & 87.8 & 37.3 & 0.034 & 33.8 & $-17.46\left(c=0.59, \mathrm{CHCl}_{3}\right)$ \\
B. cinerea AM235 & 16.2 & 83.8 & 37.3 & 0.034 & 16.7 & $-9.40\left(c=0.32, \mathrm{CHCl}_{3}\right)$ \\
\hline
\end{tabular}

Table 3. Results of preparative biotransformations of lactone 4 after 14 days.

\begin{tabular}{ccccccc}
\hline Strain & $\mathbf{4}(\mathbf{\%})$ & $\mathbf{6}(\mathbf{\%})$ & $\begin{array}{c}\text { Isolated } \\
\text { yield (\%) }\end{array}$ & $\begin{array}{c}\text { Isolated } \\
\text { yield (g) }\end{array}$ & $\boldsymbol{e e ~ ( \% )}$ & $\alpha_{D}^{20}$ \\
\hline F. culmorum AM10 & 22.7 & 77.3 & 31.7 & 0.024 & 0 & - \\
F. avenaceum AM11 & 41.6 & 58.4 & 30.2 & 0.023 & 12.8 & $-4.56\left(c=0.59, \mathrm{CHCl}_{3}\right)$ \\
F. oxysporum AM13 & 33.0 & 67.0 & 28.6 & 0.021 & 19.0 & $-9.44\left(c=0.77, \mathrm{CHCl}_{3}\right)$ \\
F. semitectum AM20 & 37.3 & 62.7 & 43.0 & 0.032 & 16.2 & $-7.11\left(c=0.94, \mathrm{CHCl}_{3}\right)$ \\
F. solani AM203 & 33.7 & 66.3 & 38.0 & 0.028 & 32.0 & $-33.42\left(c=1.00, \mathrm{CHCl}_{3}\right)$ \\
B. cinerea AM235 & 7.3 & 92.7 & 59.0 & 0.044 & 8.9 & $-2.20\left(c=0.99, \mathrm{CHCl}_{3}\right)$ \\
\hline
\end{tabular}


Table 4. Results of preparative biotransformations of lactone 5 after 14 days.

\begin{tabular}{|c|c|c|c|c|c|c|c|}
\hline Strain & $\begin{array}{c}4 \\
(\%)\end{array}$ & $\begin{array}{c}6 \\
(\%)\end{array}$ & $\begin{array}{c}7 \\
(\%)\end{array}$ & $\begin{array}{l}\text { Isolated yield } \\
\text { of } 6(\%) / 7(\%)\end{array}$ & $\begin{array}{l}\text { Isolated yield } \\
\text { of } 6(\mathrm{~g}) / 7(\mathrm{~g})\end{array}$ & $\begin{array}{c}e e \text { of } \\
6(\%) / 7(\%)\end{array}$ & $\alpha_{D}^{20}$ \\
\hline $\begin{array}{l}\text { F. culmorum } \\
\text { AM10 }\end{array}$ & 15.2 & 39.9 & 44.9 & $5.8 / 10.9$ & $0.004 / 0.006$ & $15.3 / 0$ & $\begin{array}{c}-15.83 \\
\left(c=0.28, \mathrm{CHCl}_{3}\right) /-\end{array}$ \\
\hline $\begin{array}{c}\text { F. oxysporum } \\
\text { AM13 }\end{array}$ & 40.2 & 59.8 & - & $21.2 /-$ & $0.016 /-$ & $12.3 /-$ & $\begin{array}{c}-11.22 \\
\left(c=0.21, \mathrm{CHCl}_{3}\right)\end{array}$ \\
\hline $\begin{array}{l}\text { F. solani } \\
\text { AM203 }\end{array}$ & 37.4 & 55.5 & - & $11.1 /-$ & $0.008 /-$ & $25.1 /-$ & $\begin{array}{c}-33.42 \\
\left(c=0.38, \mathrm{CHCl}_{3}\right)\end{array}$ \\
\hline
\end{tabular}

During the earlier analysis of the structure of iodolactone 5, it was shown that the signals of the H-1 and $\mathrm{H}-2$ protons were multiplets with very small coupling constants, indicating their trans diequatorial positions and the trans diaxial positions of the iodine atom and the $\mathrm{C}-\mathrm{O}$ bond.

The analysis of the ${ }^{1} \mathrm{H}$-NMR spectrum of hydroxy- $\gamma$-lactone 7 in comparison to halolactones $\mathbf{3}, \mathbf{4}$ and 5 led to the confirmation that the $\mathrm{H}-1$ proton, which was a doublet with a small coupling constant $(J=3.1 \mathrm{~Hz})$, was located in an equatorial position. However, the H-2 proton gave a wide mutiplet, which suggested its axial position.

For the determination of the changes in structure of the hydroxylactone 6 relative to the iodolactone 5, two additional ${ }^{1} \mathrm{H}-\mathrm{NMR}$ spectra were recorded: COSY and HMQC. The analysis of these spectra led to the determination of differences between these two lactones. In the case of hydroxylactone $\mathbf{6}$, some proton signals moved toward a higher field, especially the $\mathrm{H}-1, \mathrm{H}-2$ and $\mathrm{H}-3$ protons. The signal of the H-1 proton moved from $4.55 \mathrm{ppm}$ (for iodolactone 5) to $4.25 \mathrm{ppm}$ (for hydroxylactone 6), while the signal of the axial H-3 proton moved from $1.59 \mathrm{ppm}$ (for 5) to $1.22 \mathrm{ppm}$ (for 7). The biggest difference was visible for the signal from the $\mathrm{H}-2$ proton, which changed its location from $4.70 \mathrm{ppm}$ (for 5) to $3.80 \mathrm{ppm}$ (for 6). The shape of the signal of the H-2 proton gave a wide mutiplet which suggested its axial position. The doublet of the H-1 proton with a small coupling constant $(J=3.1 \mathrm{~Hz})$ indicated its equatorial position. In the case of the H-3 proton, the signal was a doublet of doublets of doublets for lactone 5 and a doublet of doublets for lactone 6; the coupling constants changed from 15.3, 11.5 and $3.9 \mathrm{~Hz}$ for iodolactone 5 to 12.4 and $12.2 \mathrm{~Hz}$ for hydroxylactone $\mathbf{6}$.

Scheme 3. Equatorial location of hydroxy group in lactone 6 as the stereochemical consequence of microbial hydrolytic dehalogenation of chloro- (3), bromo- (4) and iodolactone (5) proceeding with the inversion at C-2.
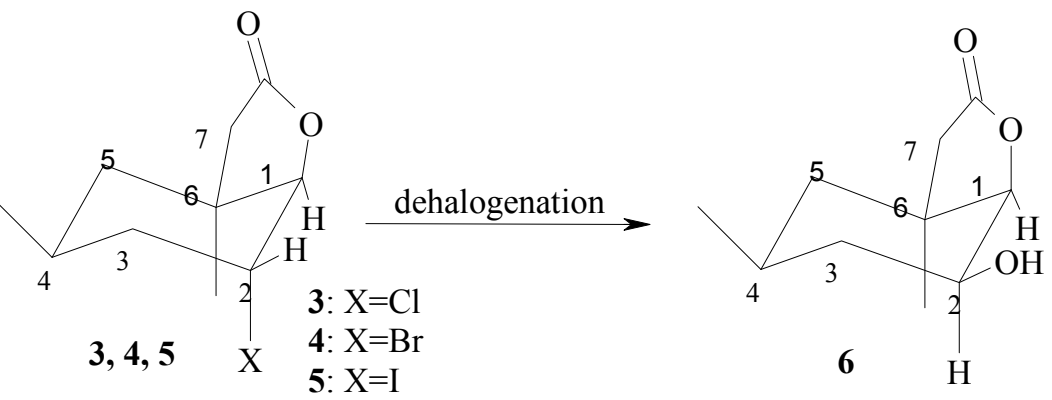

These observations confirmed that in hydroxylactone $\mathbf{6}$, the $\mathrm{H}-2$ proton and the $\mathrm{C}-\mathrm{O}$ bond were in trans diaxial positions, while the $\mathrm{H}-1$ proton and the $\mathrm{OH}$ group were situated in trans diequatorial 
positions. These results indicate that the $\mathrm{OH}$ group was cis oriented in relation to the lactone ring. It suggested also that mechanism of the reaction of the hydrolytic dehalogenation is similar to the $\mathrm{S}_{\mathrm{N}} 2$ substitution (Scheme 3).

The second product of biotransformation of iodolactone 5 was an unsaturated lactone 7. It was identified due to the presence of the characteristic signal from a double bond (between 5.80 and $5.95 \mathrm{~Hz}$ ) on the ${ }^{1} \mathrm{H}-\mathrm{NMR}$ spectra.

The optical activity of all hydroxylactones obtained from halolactones during the preparative biotransformations was measured. The enantioselectivity of biotransformation is taken under consideration to evaluate the ability of microorganisms to transform selected substrates into new products. Enantiomeric excess was determined by GC using a chiral column (Beta Dex, $30 \mathrm{~m} \times 0.25 \mathrm{~mm} \times 0.25 \mu \mathrm{m})$. The results are shown in Tables $2-4$. In almost every case, the (-) isomer of lactone 6 was created. Only when chlorolactone 3 was transformed by $F$. avenaceum was the $(+)$ isomer of $\mathbf{6}$ observed; however, when bromolactone $\mathbf{6}$ was transformed by F. culmorum, the product was a racemic mixture. The enantiomeric excess for all products was very low (from $6.7 \%$ to $33.8 \%$ ). The best result (ee $=25.1 \%$ to $33.8 \%$ ) was observed when $F$. solani was used as the biocatalyst.

\section{Experimental}

\subsection{General}

The progress of chemical reactions and biotransformations and the purity of isolated products were monitored by the TLC technique on silica gel-coated aluminium plates (DC-Alufolien Kieselgel 60 F254, Merck) and by GC analysis which was carried out on a Varian CP-3380 instrument using an HP-5 column (cross-linked methyl silicone gum, $30 \mathrm{~m} \times 0.32 \mathrm{~mm} \times 0.25 \mu \mathrm{m}$ ). The temperatures during GC analysis were as follows: injector $150{ }^{\circ} \mathrm{C}$, detector (FID) $300{ }^{\circ} \mathrm{C}$, column temperature: $100{ }^{\circ} \mathrm{C}$ (hold $1 \mathrm{~min}$ ), $100-200{ }^{\circ} \mathrm{C}$ (rate $10{ }^{\circ} \mathrm{C} / \mathrm{min}$ ), 200-300 (rate $50{ }^{\circ} \mathrm{C} / \mathrm{min}$ ), $300{ }^{\circ} \mathrm{C}$ (hold $1 \mathrm{~min}$ ). The enantiomeric compositions of the products obtained during biotransformation were determined by GC analysis using the chiral column CP-cyclodextrin-B-325 $(30 \mathrm{~m} \times 0.25 \mathrm{~mm} \times 0.25 \mu \mathrm{m})$ under the following conditions: injector $200^{\circ} \mathrm{C}$, detector (FID) $250{ }^{\circ} \mathrm{C}$, column temperature: $140{ }^{\circ} \mathrm{C}$ (hold $45 \mathrm{~min}$ ), 140-200 ${ }^{\circ} \mathrm{C}$ (rate $20{ }^{\circ} \mathrm{C} / \mathrm{min}$ ), $200{ }^{\circ} \mathrm{C}$ (hold $1 \mathrm{~min}$ ). All products were purified by means of preparative column chromatography on silica gel (Kieselgel 60, 230-400 mesh). ${ }^{1} \mathrm{H}-\mathrm{NMR}$ and ${ }^{13} \mathrm{C}$ - NMR spectra were recorded in a $\mathrm{CDCl}_{3}$ solution on a Bruker Avance DRX 300 spectrometer. The assignments of

${ }^{13} \mathrm{C}-\mathrm{NMR}$ chemical shifts were made by means of $\mathrm{C} / \mathrm{H}$ correlation heteronuclear multiple quantum coherence (HMQC). IR spectra were determined using FTIR on a Thermo-Mattson IR 300 spectrometer. Optical rotations were measured on an Autopol IV automatic polarimeter (Rudolph). Elemental analysis was done using Vario EL III CHNS automatic analyser from Elemental Analyzersysteme.

2-Chloro-4,6-dimethyl-9-oxabicyclo[4.3.0]nonan-8-one (3). A mixture of acid 2 (3.2 g, $0.019 \mathrm{~mol})$ and NCS $(3.8 \mathrm{~g}, 0.029 \mathrm{~mol})$ in THF $(30 \mathrm{~mL})$ was stirred at room temperature. After $24 \mathrm{~h}$, water was added to the mixture and the product was diluted with diethyl ether. The separated organic layer was washed with a saturated $\mathrm{NaHCO}_{3}$ solution and brine, then dried with anhydrous magnesium sulfate. The crude product was purified on silica gel (hexane-acetone, 3:1) and $2.1 \mathrm{~g}$ (yield 50\%) of chlorolactone 3 was obtained. ${ }^{1} \mathrm{H}-\mathrm{NMR}\left(\mathrm{CDCl}_{3}\right): 0.93\left(\mathrm{~d}, J=6.5 \mathrm{~Hz}, 3 \mathrm{H}, \mathrm{CH}_{3} \mathrm{C}-4\right), 1.06(\mathrm{dd}, J=13.1$ and $13.0 \mathrm{~Hz}$, one of 
$\left.\mathrm{CH}_{2}-5\right), 1.39$ (s, 3H, $\left.\mathrm{CH}_{3} \mathrm{C}-6\right), 1.53\left(\mathrm{~m}, 1 \mathrm{H}\right.$, one of $\left.\mathrm{CH}_{2}-5\right), 1.62$ (ddd, $J=15.2,12.0$ and $3.5 \mathrm{~Hz}, 1 \mathrm{H}$, one of $\left.\mathrm{CH}_{2}-3\right), 1.92\left(\mathrm{~m}, 1 \mathrm{H}\right.$, one of $\left.\mathrm{CH}_{2}-3\right), 2.05(\mathrm{~m}, 1 \mathrm{H}, \mathrm{H}-4), 2.26$ and 2.48 (two d, $J=16.7 \mathrm{~Hz}, 2 \mathrm{H}$, $\left.\mathrm{CH}_{2}-7\right), 4.29$ (m, 1H, H-1), 4.50 (m, 1H, H-2); ${ }^{13} \mathrm{C}-\mathrm{NMR}\left(\mathrm{CDCl}_{3}\right): 21.25$ (C-9), 21.14 (C-4), 23.47 (C-10), 36.48 (C-3), 39.06 (C-6), 41.83 (C-5), 46.43 (C-7), 54.70 (C-2), 84.06 (C-1), 174.69 (C-8); IR (KBr, cm ${ }^{-1}$ ): 2958 (s), 1788 (s), 1375 (m), 1207 (s), 1009 (m), 670 (m). Anal. Calcd. for $\mathrm{C}_{10} \mathrm{H}_{15} \mathrm{ClO}_{2}$ (202.68): C, 59.26; H, 7.46. Found: C, 59.18; H, 7.43.

2-Bromo-4,6-dimethyl-9-oxabicyclo[4.3.0]nonan-8-one (4). Acid 2 (3.2 g, $0.019 \mathrm{~mol})$ was dissolved in THF $(30 \mathrm{~mL})$, then NBS $(4.5 \mathrm{~g}, 0.025 \mathrm{~mol})$ was added. The mixture was stirred for $24 \mathrm{~h}$ at room temperature and then water was added. The product was extracted with diethyl ether. The ether fractions were combined, washed with a saturated $\mathrm{NaHCO}_{3}$ solution and brine, then dried with anhydrous magnesium sulfate. The crude product was purified on silica gel (hexane-acetone, 3:1) giving $2.3 \mathrm{~g}$ (yield 92\%) of bromolactone 4. ${ }^{1} \mathrm{H}-\mathrm{NMR}\left(\mathrm{CDCl}_{3}\right): 0.95\left(\mathrm{~d}, J=6.5 \mathrm{~Hz}, 3 \mathrm{H}, \mathrm{CH}_{3} \mathrm{C}-4\right), 1.07$ (dd, $J=16.1$ and $13.0 \mathrm{~Hz}$, one of $\left.\mathrm{CH}_{2}-5\right), 1.45\left(\mathrm{~s}, 3 \mathrm{H}, \mathrm{CH}_{3} \mathrm{C}-6\right), 1.56(\mathrm{dm}, J=16.1 \mathrm{~Hz}, 1 \mathrm{H}$, one of $\left.\mathrm{CH}_{2}-5\right), 1.70$ (ddd, $J=15.2,11.7$ and $3.5 \mathrm{~Hz}, 1 \mathrm{H}$, one of $\left.\mathrm{CH}_{2}-3\right), 1.97\left(\mathrm{~m}, 1 \mathrm{H}\right.$, one of $\left.\mathrm{CH}_{2}-3\right), 2.09(\mathrm{~m}, 1 \mathrm{H}$, $\mathrm{H}-4$ ), 2.27 and 2.48 (two d, $J=16.7 \mathrm{~Hz}, 2 \mathrm{H}, \mathrm{CH}_{2}-7$ ), 4.43 (m, 1H, H-1), 4.57 (m, 1H, H-2); ${ }^{13} \mathrm{C}-\mathrm{NMR}$ $\left(\mathrm{CDCl}_{3}\right)$ : 21.30 (C-9), 21.88 (C-4), 24.15 (C-10), 37.52 (C-3), 39.15 (C-6), 40.68 (C-2), 41.95 (C-5), 46.62 (C-7), 85.33 (C-1), 174.38 (C-8); IR (KBr, cm ${ }^{-1}$ ): 2954 (s), 1789 (s), 1371 (m), 1204 (s), 1002 (s), 632 (m). Anal. Calcd. for $\mathrm{C}_{10} \mathrm{H}_{15} \mathrm{BrO}_{2}$ (247.13): C, 48.60; H, 6.12. Found: C, 48.57; H, 6.17.

2-Iodo-4,6-dimethyl-9-oxabicyclo[4.3.0]nonan-8-one (5). ${ }^{1} \mathrm{H}-\mathrm{NMR}\left(\mathrm{CDCl}_{3}\right): 0.97(\mathrm{~d}, J=6.6 \mathrm{~Hz}, 3 \mathrm{H}$, $\left.\mathrm{CH}_{3} \mathrm{C}-4\right), 1.09$ (dd, $J=13.2$ and $12.9 \mathrm{~Hz}$, one of $\left.\mathrm{CH}_{2}-5\right), 1.50\left(\mathrm{~m}, 1 \mathrm{H}\right.$, one of $\left.\mathrm{CH}_{2}-5\right), 1.53(\mathrm{~s}, 3 \mathrm{H}$, $\left.\mathrm{CH}_{3} \mathrm{C}-6\right), 1.59$ (ddd, $J=15.3,11.5$ and $3.9 \mathrm{~Hz}, 1 \mathrm{H}$, one of $\left.\mathrm{CH}_{2}-3\right), 1.97\left(\mathrm{~m}, 1 \mathrm{H}\right.$, one of $\left.\mathrm{CH}_{2}-3\right), 2.07$ (m, 1H, H-4), 2.25 and 2.47 (two d, $\left.J=16.8 \mathrm{~Hz}, 2 \mathrm{H}, \mathrm{CH}_{2}-7\right), 4.55$ (m, 1H, H-1), 4.70 (m, 1H, H-2); ${ }^{13} \mathrm{C}-\mathrm{NMR}\left(\mathrm{CDCl}_{3}\right): 21.34$ (C-9), 33.41 (C-4), 23.77 (C-2), 25.39 (C-10), 38.69 (C-3), 39.62 (C-6), 42.02 (C-5), 46.72 (C-7), 85.79 (C-1), 173.98 (C-8); IR (film, cm ${ }^{-1}$ ): 2924 (s), 1776 (s), 1453 (m), $1140(\mathrm{~s}), 989(\mathrm{~s}), 615$ (s).

2-Hydroxy-4,6-dimethyl-9-oxabicyclo[4.3.0]nonan-8-one (6). ${ }^{1} \mathrm{H}-\mathrm{NMR}\left(\mathrm{CDCl}_{3}\right): 0.94(\mathrm{~d}, J=6.6 \mathrm{~Hz}$, $\left.3 \mathrm{H}, \mathrm{CH}_{3} \mathrm{C}-4\right), 1.02$ (d, $J=13.2 \mathrm{~Hz}, \mathrm{H}-5_{\mathrm{ax}}$ ), 1.19 (s, 3H, $\mathrm{CH}_{3} \mathrm{C}-6$ ), 1.22 (dd, $J=12.4$ and $12.2 \mathrm{~Hz}, 1 \mathrm{H}$, H-3 $\left.3_{\mathrm{ax}}\right), 1.41$ (m, 1H, H-5 eq $), 1.60$ (m, 1H, H-4), 1.83 (dm, J=12.4 Hz, 1H, H-3 eq $), 2.00$ (m, 1H, OH), 2.31 and 2.46 (two d, $J=16.5 \mathrm{~Hz}, 2 \mathrm{H}, \mathrm{CH}_{2}-7$ ), 3.80 (m, 1H, H-2), 4.24 (d, $J=3.3 \mathrm{~Hz}, 1 \mathrm{H}, \mathrm{H}-1$ ); ${ }^{13} \mathrm{C}-\mathrm{NMR}\left(\mathrm{CDCl}_{3}\right): 21.65$ (C-10), 21.39 (C-9), 26.88 (C-4), 37.41 (C-3), 40.54 (C-6), 41.21 (C-5), 46.25 (C-7), 68.07 (C-2), 85.81 (C-1), 1753.56 (C-8); IR (film, cm ${ }^{-1}$ ): 3340 (s), 2912 (s), 1788 (s), 1134 (s), 1052 (s). Anal. Calcd. for $\mathrm{C}_{10} \mathrm{H}_{15} \mathrm{O}_{3}$ (184.24): C, 65.20; H, 8.75. Found: C, 65.15; H, 8.71.

4,6-Dimethyl-9-oxabicyclo[4.3.0]non-2-en-8-one (7). ${ }^{1} \mathrm{H}-\mathrm{NMR}\left(\mathrm{CDCl}_{3}\right): 1.04(\mathrm{~d}, J=7.1 \mathrm{~Hz}, 3 \mathrm{H}$, $\left.\mathrm{CH}_{3} \mathrm{C}-4\right), 1.15$ (s, 3H, $\left.\mathrm{CH}_{3} \mathrm{C}-6\right), 1.22\left(\mathrm{dd}, J=13.0\right.$ and $6.4 \mathrm{~Hz}, 1 \mathrm{H}$, one of $\left.\mathrm{CH}_{2}-5\right), 1.52(\mathrm{dd}, J=13.0$ and $4.9 \mathrm{~Hz}, 1 \mathrm{H}$, one of $\left.\mathrm{CH}_{2}-5\right), 2.24(\mathrm{~m}, 1 \mathrm{H}, \mathrm{H}-4), 2.33$ and $2.52\left(\mathrm{dd}, J=17.2 \mathrm{~Hz}, 2 \mathrm{H}, \mathrm{CH}_{2}-7\right), 4.31$ $(\mathrm{d}, J=4.3 \mathrm{~Hz}, 1 \mathrm{H}, \mathrm{H}-1), 5.83$ (ddd, $J=10.0,4.3$ and $2.4 \mathrm{~Hz} 1 \mathrm{H}, \mathrm{H}-3), 5.94$ (d, $J=10.0 \mathrm{~Hz}, 1 \mathrm{H}$, H-2); IR (film, $\mathrm{cm}^{-1}$ ): 1780 (s), 1651 (m), 1212 (s), 999 (s). 


\subsection{Microorganisms}

The fungal strains, which were used in this study, were obtained from the collection of the Institute of Biology and Botany, Medical University, Wrocław (Fusarium culmorum AM10, Fusarium avenaceum AM11, Fusarium oxysporum AM13, Fusarium tricinctum AM16, Fusarium semitectum AM20, Fusarium solani AM203, Botrytis cinerea AM235 and Beauveria bassiana AM278). They all are available in Department of Chemistry, University of Environmental and Life Sciences. These strains were cultivated on Sabouraud's agar containing $5 \mathrm{~g}$ of aminobac, $5 \mathrm{~g}$ of peptone, $40 \mathrm{~g}$ of glucose and $15 \mathrm{~g}$ of agar dissolved in $1 \mathrm{~L}$ of distilled water at $28{ }^{\circ} \mathrm{C}$ and stored in refrigerator at $4{ }^{\circ} \mathrm{C}$.

\subsection{Screening Biotransformation}

In all transformation experiments, the fungal strains were cultivated on a rotary shaker at $25{ }^{\circ} \mathrm{C}$ in two Erlenmeyer flasks which contained $100 \mathrm{~mL}$ of medium containing $3 \mathrm{~g}$ of glucose and $1 \mathrm{~g}$ of peptobac in water $(100 \mathrm{~mL})$. After 4 days, $10 \mathrm{mg}$ of the substrate dissolved in $1 \mathrm{~mL}$ of acetone was added to the culture in each flask. Incubation of the shaken cultures with the substrate was continued for 14 days. After 5, 9 and 14 days of incubation, $30 \mathrm{~mL}$ of the reacting mixture including mycelium, unreacted substrate and expected product was taken from the two flasks and extracted with $30 \mathrm{~mL}$ of dichloromethane. After evaporated the solvent the residue was dissolved in $2 \mathrm{~mL}$ of acetone and analyzed by TLC (silica gel, hexane-acetone, 3:1) and GC (HP-5 column).

\subsection{Preparative Biotransformation}

The halolactones 3-5 (100 mg) were dissolved in $10 \mathrm{~mL}$ of acetone and distributed between 10 Erlenmeyer flasks with the 4-day cultures of fungal strains prepared as described in the screening procedure. The selected microorganisms were incubated with the substrates for 14 days, then the products were extracted with dichloromethane $(3 \times 50 \mathrm{~mL})$. The organic solutions were dried $\left(\mathrm{MgSO}_{4}\right)$ and the solvent was evaporated in vacuo. Mixtures containing the product, the unreacted substrate and metabolites of the fungi were separated by column chromatography (silica gel, hexane:acetone $3: 1$ ) to obtain pure products.

\section{Conclusions}

The filamentous fungal strains chosen for the conversion of halolactones $\mathbf{3}, \mathbf{4}$ and $\mathbf{5}$ showed very high regio- and stereoselectivity. The $\mathrm{OH}$ group was introduced at C-2 in the equatorial position. Since the halogen atom was in an axial position in all three substrates, this allowed us to conclude that the hydrolytic dehalogenation reaction proceeded analogously to the mechanism of $\mathrm{S}_{\mathrm{N}} 2$ nucleophilic substitution. Two substrates, chlorolactone $\mathbf{3}$ and bromolactone 4, were transformed by five and six fungal strains, respectively, in good yield (conversions over 50\%). The iodolactone 5 was transformed by only three microorganisms in yields over $50 \%$, and additionally this substrate gave an unsaturated lactone $\mathbf{7}$ in some cases. The best microorganisms for the transformation of halolactones $\mathbf{3}, \mathbf{4}$ and $\mathbf{5}$ in the best yields were F. solani, F. oxysporum and B. cinerea. Taking into account its ability to transform substrates with high enantiomeric excess, the best biocatalyst was $F$. solani. 


\section{Acknowledgments}

This project was financed by European Union from the European Regional Development Fund. Grant No. POIG. 01.03.01-00-158/09.

\section{References}

1. Vairappan, C.S.; Suzuki, M.; Ishii, T.; Okino, T.; Abe, T.; Masuda, M. Antibacterial activity of halogenated sesquiterpenes from Malaysian Laurencia spp. Phytochemistry 2008, 69, 2490-2494.

2. Ji, N.Y.; Li, X.M.; Wang, B.G. Sesquiterpenes and Other Metabolites from the Marine Red Alga Laurencia composita (Rhodomelaceae). Helv. Chim. Acta 2010, 93, 2281-2286.

3. Kladi, M.; Vagias, C.; Papazafiri, P.; Furnari G.; Serio, D.; Roussis, V. New sesquiterpenes from the red alga Laurencia microcladia. Tetrahedron 2007, 63, 7606-7611.

4. Su, H.; Shi, D.Y.; Li, J.; Guo, S.J.; Li, L.L.; Yuan, Z.H.; Zhu, X.B. Sesquiterpenes from Laurencia similes. Molecules 2009, 14, 1889-1897.

5. Rudi, A.; Benayahu, Y.; Kashman, Y. Negombins A-I, new chlorinated polyfunctional diterpenoids from the marine sponge Negombata species. Org. Lett. 2007, 9, 2337-2340.

6. Sung, P.J.; Chiang, M.Y.; Tsai, W.T.; Su, J.H.; Su, Y.M.; Wu, Y.C. Chlorinated briarane-type diterpenoids from the gorgonian coral Ellisella robusta (Ellisellidae). Tetrahedron 2007, 63, 12860-12865.

7. Diaz-Marrero, A.R.; Brito, I.; de la Rosa, J.M.; D’Croz, L.; Fabelo, O.; Ruiz-Perez, C.; Darias, J.; Cueto, M. Novel lactone chamigrene-derived metabolites from Laurencia majuscule. Eur. J. Org. Chem. 2009, 1407-1411.

8. Reed, K.A.; Manam, R.R.; Mitchell, S.S.; Xu, J.; Teisan, S.; Chao, T.H.; Deyanat-Yazdi, G.; Neuteboom, S.T.C.; Lam, K.S.; Potts, B.C.M. Salinosporamides D-J from the marine actinomycete Salinispora tropica, bromosalinosporamide, and thioester Derivatives are potent inhibitors of the 20S proteasome. J. Nat. Prod. 2007, 70, 269-276.

9. Levenfors, J.J.; Hedman, R.; Thaning, C.; Gerhardson, B.; Welch, C.J. Broad-spectrum antifungal metabolites produced by the soil bacterium Serratia plymuthica A 153. Soil Biol. Biochem. 2004, $36,677-685$.

10. Thaning, C.; Welch, C.J.; Borowicz, J.J.; Hedman, R.; Gerhardson, B. Suppression of Sclerotinia sclerotiorum apothecial formation by the soil bacterium Serratia plymuthica: Identification of a chlorinated macrolide as one of the causal agents. Soil Biol. Biochem. 2001, 33, 1817-1826.

11. Gutirrez-Cepeda, A.; Fernndez, J.J.; Gil, L.V.; Lopez-Rodriguez, M.; Norte. M.; Souto, M.L. Nonterpenoid C15 Acetogenins from Laurencia marilzae. J. Nat. Prod. 2011, 74, 441-448.

12. Nam, S.J.; Gaudncio, S.P.; Kauffman, C.A.; Jensen, P.R.; Kondratyuk, T.P.; Marler, L.E.; Pezzuto, J.M.; Fenical, W. Fijiolides A and B, inhibitors of TNF- $\alpha$-induced NFkB activation, from a marine-derived sediment bacterium of the genus Nocardiopsis. J. Nat. Prod. 2010, 73, 1080-1086.

13. Yin, S.; Boyle, G.M.; Carroll, A.R.; Kotiw, M.; Dearnaley, J.; Quinn, R.J.; Davis, R.A. Caelestines A-D, Brominated quinolinecarboxylic acids from the Australian ascidian Aplidium caelestis. J. Nat. Prod. 2010, 73, 1586-1589.

14. Lhullier, C.; Falkenberg; M.; Ioannou, E.; Quesada, A.; Papazafiri, P.; Horta, P.A.; Schenkel, E.P.; Vagias, C.; Roussis, V. Cytotoxic halogenated metabolites from the Brazilian red alga Laurencia catarinensis. J. Nat. Prod. 2010, 73, 27-32. 
15. Han, B.; McPhail, K.L.; Gross, H.; Goeger, D.E.; Mooberry, S.L.; Gerwick, W.H. Isolation and structure of five lyngbyabellin derivatives from a Papua New Guinea collection of the marine cyanobacterium Lyngbya majuscula. Tetrahedron 2005, 61, 11723-11729.

16. Zhang, L.; An, R.; Wang, J.; Sun, N.; Zhang, S.; Hu, J.; Kuai, J. Exploring novel bioactive compounds from marine microbes. Curr. Opin. Microbiol. 2005, 8, 276-281.

17. Zidorn, C.; Ellmerer, E.P.; Konwalinka, G.; Schwaiger, N.; Stuppner, H. 13-Chloro-3-O- $\beta$-Dglucopyranosylsolstitialin from Leontodon palisae: The first genuine chlorinated sesquiterpene lactone glucoside. Tetrahedron Lett. 2004, 45, 3433-3436.

18. Fehr, D.; Barlow, R.; McAtee, J.; Hemscheidt, T.K. Highly brominated antimicrobial metabolites from a marine Pseudoalteromonas sp. J. Nat. Prod. 2010, 73, 1963-1966.

19. Yang, X.; Davis, R.A.; Buchanan, M.S.; Duffy, S.; Avery, V.M.; Camp, D.; Quinn, R.J. Antimalarial bromotyrosine derivatives from the Australian marine sponge Hyattella sp. J. Nat. Prod. 2010, 73, 985-987.

20. Särkkä, J.; Paasivirta, J.; Häsänen, E.; Koistinen, J.; Manninen, P.; Mäntykoski, K.; Rantio, T.; Welling, L. Organic chlorine compounds in lake sediments. VI. Two bottom sites of Lake Ladoga near pulp mills. Chemosphere 1993, 26, 2147-2160.

21. Koistinen, J.; Herve, S.; Ruokojärvi, P.; Koponen, J.; Vartiainen, T. Persistent organic pollutants in two Finnish watercourses: Levels, congener profiles and source estimation by mussel incubation. Chemosphere 2010, 80, 625-633.

22. Papazi, A.; Kotzabasis, K. Bioenergetic strategy of microalgae for the biodegradation of phenolic compounds-Exogenously supplied energy and carbon sources adjust the level of biodegradation. J. Biotechnol. 2007, 129, 706-716.

23. Papazi, A.; Kotzabasis, K. Inductive and resonance effects of substituents adjust the microalgal biodegradation of toxical phenolic compounds. J. Biotechnol. 2008, 135, 366-373.

24. Zanaroli, G.; Pérez-Jiménez, J.R.; Young, L.Y.; Marchetti, L.; Fava, F. Microbial Reductive Dechlorination of Weathered and Exogenous Co-planar Polychlorinated Biphenyls (PCBs) in an Anaerobic Sediment of Venice Lagoon. Biodegradation 2006, 17, 19-27.

25. Hongsawat, P.; Vangnai, A.S. Biodegradation pathways of chloroanilines by Acinetobacter baylyi strain. J. Hazard Mater. 2011, 186, 1300-1307.

26. Bao, H.; Gao, J.; Liu, Y.; Su, Y. A study of biodegradation/ $\gamma$-irradiation on the degradation of pchloronitrobenzene. Radiat. Phys. Chem. 2009, 78, 1137-1139.

27. Katapodis, P.; Moukouli, M.; Christakopoulos, P. Biodegradation of indole at high concentration by persolvent fermentation with the thermophilic fungus Sporotrichum. Int. Biodeterior. Biodegradat. 2007, 60, 267-272.

28. Li, J.; Cai, W.; Zhu, L. The characteristics and enzyme activities of 4-chlorophenol biodegradation by Fusarium sp. Bioresour. Technol. 2011, 102, 2985-2989.

29. Muzikar, M.; Kresinova, Z.; Svobodova, K.; Filipova, A.; Cvancarova, M.; Cajthamlova, K.; Cajthaml, T. Biodegradation of chlorobenzoic acids by ligninolytic fungi. J. Hazard. Mater. 2011, 196, 386-394.

30. Wang, C.; Xi, J.Y.; Hu, H.Y.; We, X.H. Biodegradation of Gaseous Chlorobenzene by White-rot Fungus Phanerochaete chrysosporium. Biomed. Enviro. Sci. 2008, 21, 474-478.

31. Hardman, D.J. Biotransformation of Halogenated Compounds. Crit. Rev. Biotechnol. 1991, 11, 1-40.

32. Janssen, D.B. Evolving haloalkane dehalogenases. Curr. Opin. Chem. Biol. 2004, 8, 150-159. 
33. Janssen, D.B.; Oppentocht, J.E.; Poelarends, G.J. Microbial dehalogenation. Curr. Opin. Biotechnol. 2001, 12, 254-258.

34. Grotowska, A.K.; Wawrzeńczyk, C. Lactones 13. Biotransformation of iodolactones. J. Mol. Catal. B: Enzym. 2002, 19-20, 203-208.

35. Grabarczyk, M.; Białońska, A. Biotransformations of chloro-, bromo- and iodolactone with trimethylcyclohexane system using fungal strains. Biocatal. Biotransform. 2010, 28, 408-414.

36. Gładkowski, W.; Mazur, M.; Białońska, A.; Wawrzeńczyk, C. Lactones 35. Metabolism of iodolactones with cyclohexane ring in Absidia cylindrospora culture. Enzyme Microb. Technol. 2011, 48, 326-333.

37. Borges, K.B.; Borges, W.S.; Durán-Patrón, R.; Pupo, M.T.; Bonato, P.S.; Collado, I.C. Stereoselective biotransformations using fungi as biocatalysts. Tetrahedron: Asymmetry 2009, 20, 385-397.

38. Rodrigues-Filho, E.; Magnani, R.F.; Xie, W.; Mirocha, C.J.; Pathre, S.V; Hydroxylation of the Labdane Diterpene Cupressic Acid by Fusarium graminearum. J. Braz. Chem. Soc. 2002, 13, 266-269.

39. Ghoumari, H.; Benajiba, M.H.; Garcia-Granados, A.; Fernandez, A.; Martinez, A.; Rivas, F.; Arias, J.M. Biotransformations of ent-18-acetoxy-6-ketomanoyl oxides epimers at C-13 with filamentous fungi. Phytochemistry 2006, 67, 2294-2302.

40. Garcia-Granados, A.; Fernandez, A.; Gutierrez, M.C.; Martinez, A.; Quiros, R.; Rivas, F.; Arias, J.M. Biotransformation of ent-13-epi-manoyl oxides difunctionalized at C-3 and C-12 by filamentous fungi. Phytochemistry 2004, 65, 107-115.

41. Tapia, A.A.; Vallejo, M.D.; Gouiric, S.C.; Feresin, G.E.; Rossomando, P.C.; Bustos, D.A. Hydroxylation of dehydroabietic acid by Fusarium species. Phytochemistry 1997, 46, 131-133.

42. Świzdor, A.; Kołek, T. Transformations of 4- and $17 \alpha$-substituted testosterone analogues by Fusarium culmorum. Steroids 2005, 70, 817-824.

43. Kumari, G.N.K.; Masilamani, S.; Ganesh, M.R.; Aravind, S. Microbial transformation of zaluzanin-D. Phytochemistry 2003, 62, 1101-1104.

44. Nobilec, E.; Aniol, M.; Wawrzeńczyk, C. Lactones 1. Hydroxylation of dihydro- $\beta$ campholenolactone by Fusarium culmorum. Tetrahedron 1994, 50, 10339-10344.

45. Gładkowski, W.; Grabarczyk, M.; Konopka, M.; Wawrzeńczyk, C. Lactones 20: Biohydroxylation of saturated bicyclic $\gamma$-lactones with the substituted cyclohexane system. J. Mol. Catal. B Enzym. 2004, 29, 13-17.

46. Kaplan, O.; Nikolaou, K.; Pisvejcova, A.; Martinkova, L. Hydrolysis of nitriles and amides by filamentous fungi. Enzyme Microb. Technol. 2006, 38, 260-264.

47. Bartmańska, A.; Huszcza, E.; Tronina, T. Transformation of isoxanthohumol by fungi. J. Mol. Catal. B: Enzym. 2009, 61, 221-224.

48. Marostica, M.R., Jr.; Pastore, G.M. Production of R-(+)- $\alpha$-terpineol by the biotransformation of limonene from orange essential oil, using cassava waste water as medium. Food Chem. 2007, 101, 345-350.

49. Bicas, J.L.; de Quadros, C.P.; Neri-Numa, I.A.; Pastore, G.M. Integrated process for co-production of alkaline lipase and R-(+)- $\alpha$-terpineol by Fusarium oxysporum. Food Chem. 2010, 120, 452-456.

50. Grogan, G.J.; Holland, H.L. The biocatalytic reactions of Beauveria spp. J. Mol. Catal. B: Enzym. 2000, 9, 1-32.

51. Buchanan, G.O.; Williams, L.A.D.; Reese, P.B. Biotransformation of cadinane sesquiterpenes by Beauveria bassiana ATCC 7159. Phytochemistry 2000, 54, 39-45. 
52. Buchanan, G.O.; Reese, P.B. Biotransformation of diterpenes and diterpene derivatives by Beauveria bassiana ATCC 7159. Phytochemistry 2001, 56, 141-151.

53. Qiao, L.; Xie, D.; Liu, Q.; Zou, J.; Shen, Z.; Dai, J. Microbial transformation of lovastatin by Beauveria bassiana. Acta Pharm. Sinica B 2012, 2, 300-305.

54. Aleu, J.; Collado, I.C. Biotransformations by Botrytis species. J. Mol. Catal. B: Enzym. 2001, 13, 77-93.

55. Daoubi, M.; Duran-Patron, R.; Hernandez-Galan, R.; Benharref, A.; James, R.; Hanson J.R.; Collado, I.C. The role of botrydienediol in the biodegradation of the sesquiterpenoid phytotoxin botrydial by Botrytis cinerea. Tetrahedron 2006, 62, 8256-8261.

56. Bustillo, A.J.; Aleu, J.; Hernández-Galán, R.; Collado, I.C. Biotransformation of the fungistatic compound $(R)-(+)-1-\left(4^{\prime}-\right.$ chlorophenyl)propan-1-ol by Botrytis cinerea. J. Mol. Catal. B: Enzym. 2003, 21, 267-271.

57. Paruch, E.; Ciunik, Z.; Nawrot, J.; Wawrzeńczyk, C. Lactones 9. Synthesis of terpenoid lactones-active insect antifeedants. J. Agric. Food Chem. 2000, 48, 4973-4977.

58. Paruch, E.; Nawrot, J.; Wawrzeńczyk, C. Lactones 11. Feeding-deterrent activity of some bi- and tricyclic terpenoid lactones. Pest Manag. Sci. 2001, 57, 776-780.

59. Gabryś, B.; Szczepanik, M.; Dancewicz, K.; Szumny, A.; Wawrzeńczyk, C. Environmentally Safe Insect Control: Feeding Deterrent Activity of Alkyl-Substituted $\gamma$ - and $\delta$-Lactones to Peach Potato Aphid (Myzus persicae [Sulz.]) and Colorado Potato Beetle (Leptinotarsa decemlineata Say). Polish J. Environ. Stud. 2006, 15, 549-556.

60. Wawrzeńczyk, C.; Grabarczyk, M.; Szumny, A.; Gabryś, B.; Dancewicz, K.; Nawrot, J.; Prądzyńska, A.; Halarewicz-Pacan, A. Lactones 19. Synthesis and antifeedant activity of lactones with methyl-, dimethyl- and trimethylcyclohexane system. In Chemistry for Agriculture; Górecki, H., Dobrzański, Z., Kafarski, P., Eds.; Czech-Pol Trade: Wrocław, Poland, 2003; pp. 117-129.

61. Szczepanik, M.; Grabarczyk, M.; Szumny, A.; Wawrzeńczyk, C. Feeding detergent activity of lactones with di- and trimethylcyclohexane system against lesser mealworm, Alphitobius diaperinus Panzer and Colorado potato beetle (Leptinotarsa decemlineata Say). J. Plant Prot. Res. 2003, 43, 87-96.

62. Dancewicz, K.; Gabryś, B.; Halarewicz-Pacan, A.; Grabarczyk, M.; Wawrzeńczyk, C. Effect of terpenoid lactones with di- and trimethylcyclohexane systems on the behaviour of green peach aphid Myzus persicae. Pesticydy (Pesticides) 2005, 4, 17-23.

63. Grabarczyk, M.; Szumny, A.; Gładkowski, W.; Białońska, A.; Ciunik, Z.; Wawrzeńczyk, C. Lactones 18. Synthesis of bicyclic lactones with methyl-, di- and trimethyl substituted cyclohexane system. Pol. J. Chem. 2005, 79, 1763-1771.

Sample Availability: Samples of the compounds 3-7 are available from the authors.

(C) 2012 by the author; licensee MDPI, Basel, Switzerland. This article is an open access article distributed under the terms and conditions of the Creative Commons Attribution license (http://creativecommons.org/licenses/by/3.0/). 